\title{
Structural power: the limits of neorealist power analysis \\ Stefano Guzzini
}

The origin of this conceptual analysis lies in a basic puzzle. How did power analysis increasingly turn from a defense to a critique of realism? I shall argue that the turn from realism to neorealism, with its consequent reliance on economic methodology, in fact diminished the substantial range of the original concept of power. This article will contend that taking power analysis seriously leads beyond neorealism.

Some recent studies by authors dissatisfied with neorealism have attempted to widen the power concept to include what has been called structural power. Their common claim is that the focus on strategic interaction or the bargaining level of analysis does not capture important power phenomena. I shall argue that these notions of structural power involve three distinct meanings, of which only one can be shown to be compatible with the interactionist choicetheoretical power concept that underlies the neorealist approach.

Finally, this essay claims that none of the structural power concepts is able to provide both a comprehensive and a coherent power analysis, either because it still omits particular power phenomena or because it overloads the concept of power. Instead of pursuing the track of continuously widening the concept, this article will propose a pair or dyad of concepts. The word "power" will be reserved as an agent concept, and the term "governance" will represent effects not due to a particular agent, whether individual or collective. More generally, I shall use the term "power analysis" to encompass both concepts and to deal with the link between power and international governance.

By approaching power from the methodological level, this essay presents a more systematic analysis than those that either take the form of reviews or

For helpful comments and suggestions on drafts of this article as early as June 1990, I am indebted to James Coleman, Robert Cox, Stephen Gill, Pierre Hassner, Anna Leander, Steven Lukes, Reinhard Meyers, Heikki Patomäki, Susan Strange, Ole Wæver, and the editor and two anonymous referees of International Organization. I would also like to thank Peter Taylor and Holly Wyatt who helped me to improve the language. 
enumerations of different approaches or else do not consider the literature beyond David Baldwin's work. ${ }^{1}$

A last preliminary remark concerns the underlying definition of neorealism in the argument pursued here. The contribution of neorealism has been the systematic use of an economic mode of explanation in international relations (IR). This implies both (1) the Waltzian use of market theory and (2) the rational-actor model used in the game-theoretical approach and most prominently by Robert Keohane and Joseph Nye, Jr.'s later research program. It is on this ground that insights from the traditional realist and liberal traditions recently have been integrated..$^{2}$ The thorny question of whether Waltzian (so-called structural) neorealism is indeed linked to a rational-choice (individualist) model has spurred a major debate. ${ }^{3}$ The position followed here is in essence closer to that of Alexander Wendt and Richard Ashley. Martin Hollis and Steve Smith are right that neoclassical economic theory allows, indeed requires, a double causation at the individual and market levels. Ashley and Wendt are also right to argue that the structural explanation presupposes the existence and the constancy of the actor's preferences. Indeed, only by presupposing homo economicus (Kenneth Waltz's like-unit), a being who wants to survive in his environment (basic preference) and manages to do so by rationally calculating the costs and benefits of alternate actions, can market (anarchy) constraints be understood. Economic theory is very powerful because it conceals and inextricably links these two levels. At the market level,

1. See, respectively, Richard L. Sklar, "On the Concept of Power in Political Economy," in Dalmas H. Nelson and Richard L. Sklar, eds., Towards a Humanistic Science of Politics: Essays in Honor of F. Dunham Wortmuth (Lanham, Md.: University Press of America, 1983), pp. 179-206; and James Caporaso and Stephen Haggard, "Power in the International Political Economy," in Richard J. Stoll and Michael D. Ward, eds., Power in World Politics (Boulder, Colo.: Lynne Rienner Publishers, 1989), pp. 99-120. David A. Baldwin's "Interdependence and Power: A Conceptual Analysis," International Organization 34 (Autumn 1980), pp. 471-506 is the last reference in Graham Evans and Jeffrey Newnham, eds., The Dictionary of World Politics: A Reference Guide to Concepts, Ideas and Institutions (New York: Harvester Wheatsheaf, 1990), pp. 322-24.

2. Robert O. Keohane and Joseph S. Nye, Jr., "Power and Interdependence Revisited," International Organization 41 (Autumn 1987), pp. 725-53. In particular, see p. 729, wherein Keohane and Nye explicitly subsume liberalism and realism under a rational-actor model but with different conceptions of the nature of environment and other actors' goals. See also Joseph S. Nye, Jr., "Neorealism and Neoliberalism," World Politics 40 (January 1988), pp. 235-51; and, explicitly, Robert O. Keohane, "International Institutions: Two Approaches," in Robert Keohane, Intemational Institutions and State Power: Essays in International Relations Theory (Boulder, Colo.: Westview Press, 1989), pp. 158-79. For the purpose of this argument, only the neoinstitutionalist and regime approaches that use an economic mode of explanation can be criticized accordingly.

3. See Richard Ashley, "The Poverty of Neorealism," in Robert O. Keohane, ed., Neorealism and its Critics (New York: Columbia University Press, 1986), pp. 158-203; Alexander Wendt, "The Agent-Structure Problem in International Relations," International Organization 41 (Summer 1987), pp. 337-70; Alexander Wendt, "Bridging the Theory/Metatheory Gap in International Relations," Review of Intermational Studies 17 (October 1991), pp. 383-92; and Martin Hollis and Steve Smith, "Beware of the Gurus: Structure and Action in International Relations," Review of International Studies 17 (October 1991), pp. 399-403. See also the rejoinders: Alexander Wendt, "Levels of Analysis vs. Agents and Structures: Part III," Review of International Studies 18 (April 1992), pp. 181-85; and Martin Hollis and Steve Smith, "Structure and Action: Further Comment," in the same issue, pp. 187-88. 
dynamics are the result of individual utilitarian value-maximizing behavior. At the individual level, the static market constraints are the permanent background against which the strategic behavior of individuals is articulated. To allow for the explanatory articulation of the two levels of neoclassical theory, both individual preferences (in the macroanalysis) and the so-called invisible working of the market (in the microanalysis) must be taken for granted theoretically and held constant in the analysis. Without them, marginal economics could not work. In other words, rational choice and a Waltzian analysis are merely the two different levels of the same economic (utilitarian and interactionist) approach.

The argument will be pursued in three steps. A first part will introduce the methodology of this conceptual analysis and the power concept underlying neorealism. Next, the article will analyze three meanings of structural power. Finally, I shall propose a more coherent power analysis characterized by a dyad of concepts.

\section{A conceptual critique of power in neorealism}

The particular analysis and criticisms of recent conceptualizations of power proposed here call for a short justification of why at this particular moment a new conceptual analysis of power is required. After some major methodological assumptions regarding conceptual analyses in general have been outlined, an appraisal of the previous power debates in IR will introduce the underlying concept of power in neorealism.

\section{Aims and limits of a conceptual analysis}

The present analysis is not concerned with the empirical assessment of power; rather, it proposes a conceptual analysis of power and does so in the particular situation of a discipline in crisis. Currently, the discipline of IR is recovering from a state of disarray exemplified by the creation of a new discipline-namely, international political economy (IPE) - and the establishment of new and legitimate research areas on the fringes of mainstream research, such as critical theory, feminist theory, and poststructuralist approaches. At times like this, reconceptualizations are unavoidable: they constitute the first stage in theory reconstruction. Conceptual analyses serve to clarify and systematize the meaning of the very tools that different theories can then use to formulate explanations. In this respect, it is essential to recall that concepts are the basis for explanations and are not explanations as such. There might be theories involving power that can be checked empirically, but there are no concepts that can be checked in this way. Theories explain, concepts do not. Thus, this conceptual analysis falls short of claiming to provide the theory of power. The aim of this conceptual analysis is to provide a pretheoretical 
check of the coherence with which the concept of power is used in explanations and extended in recent writings for and against neorealism. It represents a logical control of theories before they are applied to empirical material. ${ }^{4}$

The theory dependence of the concept of power entails that there is no single concept of power applicable to every type of explanation. This implies that a limited range of views about power can be held that are both reasonable and yet different, possibly even incompatible. ${ }^{5}$ At least three different reasons have been put forward to argue for the concept of power as being "essentially contested."

First, power always implies an element of counterfactual reasoning; that is, the judgment of the significance of a given set of abilities (power) presupposes an implicit statement about the unaffected state of affairs. Power implies potential change, which in turn implies a counterfactual situation of potential continuity. Since counterfactual situations are difficult to assess empirically, so this argument runs, no decisive proof can be brought in favor of one approach.

Second, it has been argued that the concept of power (as related to personal autonomy or interests) cannot be disentangled from normative discourse. ${ }^{6}$ Derived from this idea is the view in IR that "incommensurable" paradigms or ideologies meet in an "interparadigm debate." Thomas Kuhn's concepts provided a welcome explanation for the discipline's difficulties in accumulating knowledge at a time when realism had lost its hegemony. The interparadigm debate argued for the establishment and recognition of rival schools of thought that cannot be subsumed under any form of revised realism. Once accepted, however, Kuhn's concepts became a welcome protective shield used by realists (and others) against attacks from other schools. Now, the concept of incommensurability legitimizes business as usual at the price of a predefined pluralism. ${ }^{8} \mathrm{~A}$ specific historical stage of the debate in IR has become reified into rigid categories. These categories are inherently heterogeneous and are becoming increasingly confused with the (Anglo-American) ideological triad of conserva-

4. This is also a requisite of a strictly positivist approach that insists on the prior clarification of the central variables and their meaning. For a classic statement, see Carl G. Hempel, Aspects of Scientific Explanation and Other Essays in the Philosophy of Science (London: Free Press, 1965).

5. William E. Connolly, The Terms of Political Discourse, 2d ed. (Oxford: Martin Robertson, 1973), chap. 1.

6. See especially Steven Lukes, Power: A Radical View (London: Macmillan, 1974).

7. Michael Banks, "The Inter-paradigm Debate," in M. Light and A. J. R. Groom, eds., International Relations: A Handbook of Current Theory (London: Frances Pinter, 1985), pp. 7-26. For the term "ideology," in IPE, see Robert Gilpin, The Political Economy of Intermational Relations (Princeton, N.J.: Princeton University Press, 1987). For an impressive list of the widely proposed trilogies, see Volker Rittberger and Hartwig Hummel, "Die Disziplin 'Internationale Beziehungen' im deutschsprachigen Raum auf der Suche nach ihrer Identität: Entwicklung und Perspektiven" (The discipline of 'international relations' in German-speaking countries in search of its identity: evolution and perspectives"), in Volker Rittberger, ed., Theorien der intemationalen Beziehungen: Bestandsaufnahme und Forschungsperspektiven (Theories of international relations: the state of the art and research perspectives) (Opladen, Germany: Westdeutscher Verlag, 1990), p. 23.

8. For this attitude, see especially K. J. Holsti, The Dividing Discipline: Hegemony and Diversity in International Theory (Boston: Allen \& Unwin, 1985). 
tism, liberalism, and radicalism without any theoretical discussion of why specific ideologies would require particular theories and methodologies. ${ }^{9}$

Therefore, I shall not develop a so-called realist as opposed to a so-called liberal/pluralist or so-called critical/Marxist concept of power, assuming such things exist. Given that concepts of power are widely used as central explanatory variables, I find the underlying metatheoretical differences that characterize modes of explanation to be a more fundamental level at which those concepts can be distinguished. This third reason for essential contestability is a constructivist approach that is arguably more Kuhnian than the interparadigm debate. By mode of explanation, I mean the particular cluster of ontologies (agent/structure) and epistemologies (naturalist/interpretivist) that underlie theories and their reconstruction of reality. ${ }^{10}$ Alexander Wendt and Raymond Duvall have written: "Although social ontologies do not directly dictate the content of substantive theories, they do have conceptual and methodological consequences for how theorists approach those phenomena they seek to explain, and thus for the development of their theories."11 Concepts are not self-sufficient. They derive their meaning more generally from their modes of explanation and particularly from the theories (e.g., realism) in which they are embedded. ${ }^{12}$ As will be shown, power is significantly different if conceived in an interactionist, dispositional, or intersubjective/structuralist approach. ${ }^{13}$ This insight, which informs the whole of the following conceptual analysis, could be called explanatory perspectivism. It implies that concepts can be checked on the basis of their coherence within their respective theoretical frameworks. ${ }^{14}$ It furthermore entails that, for the purpose of this study, it makes no significant difference who is the particular reference for power, provided the theory using power is constructed in the same mode of explanation. For instance, interaction-

9. For more details, see Stefano Guzzini, "T. S. Kuhn and International Relations: International Political Economy and the Inter-paradigm Debate," Master's thesis, London School of Economics and Political Science, 1987; and Stefano Guzzini, "The Continuing Story of a Death Foretold: Realism in International Relations/International Political Economy," EUI Working Papers SPS no. 92/20, (Florence, Italy: European University Institute, 1992), especially chaps. 10 and 16.

10. For the same metatheoretical division, see Walter Carlsnaes, "The Agency-Structure Problem in Foreign Policy Analysis," International Studies Quarterly 36 (September 1992), pp. 245-70, and in particular p. 249.

11. Alexander Wendt and Raymond Duvall, "Institutions and International Order," in Ernst-Otto Czempiel and James Rosenau, eds., Global Changes and Theoretical Challenges (Lexington, Mass.: Lexington Books, 1989), pp. 51-73. The quotation is from p. 55.

12. This is now widely acknowledged across rather different conceptualizations. See, for example, Barry Barnes, The Nature of Power (Cambridge: Cambridge University Press, 1988); Stewart Clegg, Frameworks of Power (London: Sage Publications, 1989); Richard L. Merritt and Dina A. Zinnes, "Alternative Indexes of National Power," in Richard J. Stoll and Michael D. Ward, eds., Power in World Politics (Boulder, Colo.: Lynne Rienner Publications, 1989), pp. 11-28, and in particular p. 27.

13. I use the word "structuralist" in the traditional sense of social theory, where it refers to theories that rely on holistic explanations. Waltz's approach has been, unfortunately for the interdisciplinary debate, sometimes labeled structuralist. I will refer to Waltz as a neorealist.

14. For a similar approach, see Sarah Joseph, Political Theory and Power (Leiden, The Netherlands: E. J. Brill, 1988). 
ist rational-choice approaches and the power concept they include remain basically the same in the analysis of nuclear brinkmanship, organizational agenda-setting, or personal threats. They also remain alike across the different spheres to which they are applied, whether economic, social, financial, or others. Power is distinguished through its role in explanatory frameworks, not through the fields to which it is applied.

In this way, I make two major claims. First, I try to show that concepts of structural power rightly identify the basic paradox of recent developments in realism. The neorealist move to an economic model will be shown to reduce the explanatory value of the concept of power.

The second claim is a theoretical argument against what Michael Banks once called "realism-plus-grafted-on-components," that is, the tendency of common wisdom in IR to incorporate reasonable insights without keeping track of whether doing so leads to an internal inconsistency. ${ }^{15}$ By criticizing already developed power schemes in political theory, I attempt to show that the concept of power cannot be extended indefinitely without becoming inconsistent with the underlying framework of analysis. This applies, of course, to both neorealist concepts and their challengers alike. ${ }^{16}$

The twist of the argument presented here is to make a paradox work. Realists generally believe that whatever one can say about their story, it is a story on power writ large. My contention is that by turning neorealist, they are in fact restricting themselves to a limited view of power. Some realists will not care, and the paradox will not work. Some realists might, however, hesitate and become curious about the wisdom of sticking to or moving to a choicetheoretical mode of explanation and its assumptions in which their central concept is underrated. Taking power seriously might lead realists beyond neorealism.

\section{The neorealist concept of power}

Concepts of structural power are but the latest in a series of attacks on realism through conceptual critiques of power. The neorealist concept of power itself reflects this long-standing debate.

According to traditional realism, the workings of the international system can be explained through the underlying distribution of power. This type of analysis typically identifies the contenders, their diverging interests and intentions, the open or tacit clash of wills, and the prevailing outcome. It shows which of the means that have been employed have proved most efficient. This

15. Michael Banks, "The Evolution of International Relations," in Michael Banks, ed., Conflict in World Society: A New Perspective on International Relations (Brighton, England: Harvester Press, 1984), pp. 3-21 and 18.

16. For a similar approach, see Friedrich Kratochwil and John Gerard Ruggie, "International Organization: A State of the Art on an Art of the State," International Organization 40 (Autumn 1986), pp. 753-75. 
allows the power of actors to be assessed not only for the power confrontation in question but also for future ones. One can deduce the relative power positions of actors by measuring the share of the most effective means they have under their control and can then derive guidance for future policy. This mix of explanatory and policy-planning characteristics has made the national interest as expressed in power such a "parsimonious" and ubiquitous tool in traditional IR.

However, this conception of power has often been held to conceal an essentially circular argument both for the assessment of the outcome and for the amount of power. On the one hand, it claims that (the distribution of) power is the main criterion for the explanation of outcomes. On the other, in some cases the outcomes are the main criterion for the assessment of power(s). Among other critiques, this essential circularity spurred the first major criticisms of the concept. ${ }^{17}$ As a reaction to this criticism, researchers in IR have either carefully avoided the concept of power ${ }^{18}$ or tried to state specific power links and measure the means more rigorously. It is in this context that we must see two prominent reconceptualizations of power in IR, which both use a choice-theoretical approach. This is done not by Waltz, who leaves the concept unchanged, but by Baldwin and by Keohane and Nye. ${ }^{19}$ Baldwin attempts systematically to apply insights from the pluralist literature in political theory to IR. ${ }^{20}$ Keohane and Nye explore the limits of traditional power analysis in the context of transnationalization. Even though Baldwin criticizes their use of the concept of interdependence, these two influential reworkings of the concept have many crucial points in common. Both approaches take a choicetheoretical model as their underlying methodological starting point. Both are aware of the above-mentioned tautology, which derives from defining power in terms of resources. Both stress the importance of apprehending power resources only after a careful contextual analysis that Keohane and Nye subsume under "asymmetrical interdependency." Finally, both emphasize the need to specify the context, that is, the issue-areas (and possibly also regimes) from which "vulnerability," resources, and thus potential power derive. (For instance, military resources are not necessarily useful when employed in a financial context.) As a result, they propose a choice-theoretical power analysis

17. See Ernst Haas, "The Balance of Power: Prescription, Concept, or Propaganda," World Politics 5 (July 1953), pp. 442-77; and Inis L. Claude, Jr., Power and Intemational Relations (New York: Random House, 1962).

18. James Rosenau distinguishes between "capabilities" as a property concept and "control" as actual influence over outcomes; see his 1976 essay "Capabilities and Control in an Interdependent World," in his book The Study of Global Interdependence: Essays on the Transnationalization of World Affairs (London: Frances Pinter, 1980), pp. 35-52.

19. Robert Keohane and Joseph Nye, Jr., Power and Interdependence: World Politics in Transition (Boston: Little, Brown, 1977), in particular p. 18. For Baldwin's more systematic account, see the next section of the present article.

20. For examples of the "pluralist" approach, see Robert Dahl, "Power," in David Sills, ed., International Encyclopedia of the Social Sciences, vol. 12, 1968, pp. 405-15; and Nelson W. Polsby, Community Power and Political Theory, rev. ed. (New Haven, Conn.: Yale University Press, 1980). 
TABLE 1. Meanings of structural power and related concepts

Power as the production of

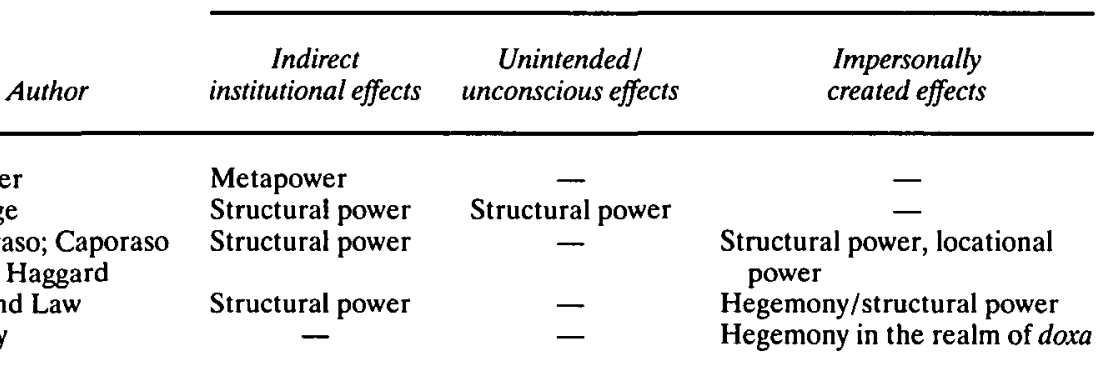

that focuses on specific "bargains" and the translation process from agent resources, which derive from particular contexts (interdependence), via strategic interaction to influence over outcomes.

Again, this new version of a realist power analysis has been found wanting. In the following section, these critiques will be presented systematically and criticized in turn.

\section{Beyond neorealism? Meanings of structural power}

Some recent studies have attempted to widen the power concept to include what has been called "structural power." I shall argue that these new notions of structural power involve three different meanings, namely, indirect institutional power, nonintentional power, and impersonal empowering (see Table 1). Only one of them is yet compatible with the underlying framework of neorealism, and none is able to provide a framework for the analysis of power phenomena that is both encompassing and coherent.

The criticisms were largely inspired by the so-called power debate in political theory. All the stages of that debate were replayed in IR. James Caporaso's and Stephen Krasner's concepts of structural power within IPE draw on Peter Bacharach and Morton Baratz's "second face of power," which tried to integrate notions like nondecision making or agenda setting. Stephen Gill and David Law's use of structural power derives from Steven Lukes's "third dimension" of power, which proposes to focus on the very power-intensive situations in which conflicts of interests are systematically ruled out before they can be voiced. Finally, Susan Strange and Richard Ashley extend power concepts beyond the "power debate." 21

21. See, respectively, Peter Bacharach and Morton Baratz, Power and Poverty: Theory and Practice (New York: Oxford University Press, 1970); and Steven Lukes, Power: A Radical View. For the IR analysts, see the following section. 


\section{Power as a relational concept: indirect institutional power as an update of neorealist power analysis}

One meaning of structural power is "indirect institutional power." Krasner's concept of metapower has to be understood as control over outcomes not via direct confrontation but by changing the setting in which confrontation occurs. Even though this seems to depart from the usual neorealist power analysis, a comparison with Baldwin's framework will show that it is in fact compatible with the assumptions of the economic approach. This concept is unsatisfactory, however, because it is too restrictive even for an agent-based concept of power.

Krasner tries explicitly to extend his particular regime analysis to embrace a form of power analysis. He analyzes how the regime concept can be located within the same conversion process from resources via power to influence (over outcomes) that we have already met in Keohane and Nye. He thus follows the traditional realist assumption that regimes are, in the last resort, still a function of the distribution of power and the relations among states. However, there need not always be congruity among power distribution, regimes, and related behavior or outcomes. In other words, there is a time lag of adjustment that allows for a certain autonomy of the realm of norms, as well as an interactive process between (power) base and norms. ${ }^{22}$ Therefore, lags and feedbacks between power base and regime are the basic puzzles of Krasner's research program. Krasner makes two points about the interaction of power and regimes. First, he argues that changes of regimes alter the context in such a way as to render particular resources more important for power capability than others. The approach thereby recovers part of what one could call the historically contingent character of power resources. ${ }^{23}$ Second, regimes can, after a time lag, be conceived of as independent sources of influence.

However, through a shift of the argument, power and regime are not only two different sources of influence but regime is in fact reduced to a source of power. Krasner has defined "power" as potential control over resources and conceived of "power resources" as those phenomena that can be used to exercise influence. It follows that normative structures and regimes can be envisaged as just another type of power source and their potential control as just another form of power. Then, one could argue, Krasner's two approaches to power and regime are fused into one. Krasner has taken this logical step by defining a second level of power relations:

The boundaries of this work can be more clearly delineated by distinguishing between two categories of political behavior. Relational power behavior refers to efforts to maximize values within a given set of institutional structures; meta-power behavior refers to efforts to change the institutions them-

22. Stephen D. Krasner, "Regimes and the Limits of Realism: Regimes as Autonomous Variables," Intemational Organization 36 (Spring 1982), pp. 497-510, and especially p. 499.

23. For this argument, see Raymond Aron, Paix et guerre entre les nations (Peace and war between nations), 8th ed. (Paris: Calmann-Lévy, 1984), p. 64. 
selves. Relational power refers to the ability to change outcomes or affect the behavior of others within a given regime. Meta-power refers to the ability to change the rules of the game. Outcomes can be changed both by altering the resources available to individual actors and by changing the regimes that condition action. ${ }^{24}$

Since regimes are a source of power, any intentional attempt to change regimes or to set new institutional frames for actors' capabilities must be integrated into power analysis. This is an indirect form of power and is often hidden or tacit. Krasner argues his case by referring to the Third World and its attempt to change the institutional settings in which North-South relations occur in order to upset the relational power advantage of the North..$^{25}$

This wider concept of metapower is consistent with neorealism's economic foundations. One way to see this is to recognize the parallel between Krasner's metapower and the power approach as developed by Baldwin, who works explicitly with an economic exchange model like that underlying neorealism. ${ }^{26}$

Baldwin defends a so-called relational approach to the analysis of power. In this approach, a power base or power resource cannot be assessed by sole reference to the power holder. Baldwin's preferred example is a coercive attempt in which a person threatens another with a gun and shouts "your money or your life." The sanction of killing and the visible means for realizing it generally provide a powerful threat. Yet, if the threatened person is preparing to commit suicide, or does not value life so highly, the coercive capacity of the threat is reduced accordingly. Awareness of this relational aspect can also be consciously used as a defense against threats. President Harry Truman tried to impress Joseph Stalin in Potsdam in 1945 by telling him that the United States had developed an atomic bomb. Stalin, however, by feigning indifference, reduced the impact of this possible bargaining chip. Thus, any power instrument becomes a potential power resource only if its control is seen to be valued

24. Stephen Krasner, Structural Conflict (Berkeley: University of California Press, 1985), p. 14. For a very similar approach, see Joseph S. Nye, Jr., "Soft Power," Foreign Policy 80 (Fall 1990), pp. 153-71, and, in particular, pp. 166-68. Above the traditional "command power," he conceives of a form of power, called "co-optive power" or "soft power," which (1) expressed in terms of resources, is derived from intangible resources like the rules in regimes and cultural and/or ideological attraction and (2) expressed in terms of power exercises, consists in structuring the situations in which power relations occur.

25. Krasner's argument was made in the context of the U.S. and the U.K. decisions to "react" against this attempt by quitting the United Nations Educational, Scientific, and Cultural Organization (UNESCO).

26. The best general presentation in political theory of the choice-theoretical approach to power remains Brian Barry's 1975 essay, "Power: An Economic Analysis," reprinted in Brian Barry, Democracy, Power, and Justice (Oxford: Clarendon Press, 1989), pp. 222-69. See also Jean Baechler, Le Pouvoir Pur (Pure power) (Paris: Calmann-Lévy, 1978); and Randall Bartlett, Economics and Power: An Inquiry into Human Relations and Markets (Cambridge: Cambridge University Press, 1989). Additionally, see Keith M. Dowding, Rational Choice and Political Power (Hants, U. K.: Edward Elgar, 1991), whose distinction between "outcome power" and "social power" reflects exactly Krasner's twofold approach. 
by other actors in the interaction. Power comes out of this relation, not from the power holder alone. ${ }^{27}$

Yet, the fundamental theoretical reason why Baldwin argues in favor of power as a relational concept, and not a possession, is to resist the moneypower analogy. This approach, stemming from the social exchange literature, treats power as a resource to be exchanged in an interaction for influence. The rejection of this analogy marks the three major elements of Baldwin's power analysis: the concept of fungibility, ${ }^{28}$ the multidimensional character of power, and the prior relational analysis of specific policy-contingency frameworks. ${ }^{29}$

The high fungibility of money rests on two main characteristics: first, its high liquidity as a medium of exchange based and dependent upon, second, its function as a standard of value. ${ }^{30}$ Yet, for Baldwin

the owner of a political power resource, such as the means to deter atomic attack, is likely to have difficulties converting this resource into another resource that would, for instance, allow his country to become the leader of the Third World. Whereas money facilitates the exchange of one economic resource for another, there is no standardized measure of value that serves as medium of exchange for political power resources. ${ }^{31}$

Because power is not fungible, it is multidimensional, i.e., its scope (the objectives of an attempt to gain influence; influence over which issue), its domain (the target of the influence attempt), its weight (the quantity of

27. On this particular point, see David A. Baldwin, Economic Statecraft (Princeton, N.J.: Princeton University Press, 1985), p. 22; and his 1980 essay "Interdependence and Power: A Conceptual Analysis" reprinted in David A. Baldwin, Paradoxes of Power (New York: Basil Blackwell, 1989), especially p. 207.

28. The term "fungibility" refers to the idea of movable goods that can be freely placed and replaced by others of the same class. It connotes universal applicability or "convertibility" in contrast to context specificity. For Baldwin, money is defined by its fungibility. He obviously refers to an ideal type of money, i.e., the most liquid part of the various money aggregates, and the fact that the standard-of-value function is fulfilled mainly in developed national economies and only to a limited extent on the international level.

29. Keohane follows this approach when, by arguing for issue- or regime-specific analyses, he specifically criticizes Waltz for this fungibility assumption. See Robert $O$. Keohane, "Theory of World Politics: Structural Realism and Beyond," in Keohane, Neorealism and Its Critics, pp. 158-203, and especially p. 184.

30. Baldwin, Paradoxes of Power, pp. 25 and 209. For a similar argument, see Arnold Wolfers, Discord and Collaboration (Baltimore, Md.: The Johns Hopkins University Press, 1962), p. 106. Aron states that only the characteristics of money allow economists to reduce the multiplicity of individual choices to a single scale of preferences. Since neither power nor "national interest" can play this role, economics cannot be the model for international theory. By criticizing Kaplan, Aron thereby anticipates and rejects Waltz's research program. Waltz explicitly acknowledges Aron's argument. He counters by claiming that the missing standard-of-value characteristics of power is not a problem for theory building but a practical problem that arises during its application. He thereby overlooks Aron's argument that the reason why money is not analogous to power lies in the lack of a theoretical analogy between utility and national interest. For the two arguments, see Aron, Paix et guerre entre les nations, p. 98; and Kenneth Waltz, "Realist Thought and Neorealist Theory," Joumal of Intemational Affairs 44 (Summer 1990), pp. 21-38, respectively.

31. David A. Baldwin, "Power Analysis and World Politics: New Trends Versus Old Tendencies," in Baldwin, Paradoxes of Power, p. 134. 
resources), and its cost (opportunity costs of forgoing a relation) must be made explicit. Without these qualifications, any statement about power is, for Baldwin, close to meaningless. Another consequence of low fungibility is that power can rest on various bases, and no single power base (military resources, for instance) can be held a priori to be the most decisive in any attempt to exert influence.

This multidimensional character leads to the last characteristic of any power approach in Baldwin's terms: the specification of the situation, that is, the policy-contingency framework (see Figure 1). A relational concept of power requires a prior contextual analysis. ${ }^{32}$ At this point, the inextricable link of the economic approach's two levels can be shown. For the agent, this policycontingency framework corresponds to the structural level of an economic approach. Only by analyzing the particular market in which (economic) actors meet is a precise assessment of the interaction possible. In this respect, Baldwin's multidimensional context resembles Keohane and Nye's issue-areas or regimes rather than the general Waltzian structure. On the other hand, agents' behavior in the long run shapes the underlying structure that constrains future actions. It is exactly on this microeconomic dynamic of structural theories that Krasner's approach of indirect power can be located.

In order to draw the analogy between Baldwin's and Krasner's approaches, a last element is needed: the necessary inclusion of societal norms in the analysis. This results from the fact that exchange is possible not only in money economies but also in situations of barter. Indeed, in such contexts there also exists a medium of exchange, even though it is a very crude one. Therefore, the analogy of barter exchange and power relations is theoretically possible..$^{33}$ Baldwin writes:

The exchange of approval for advice, of compliance for money, or of one favor for another does not require measurement in terms of commensurate units of value-at least not so long as we speak of it as direct exchange (barter). It is only when indirect exchange and the fairness of exchange are discussed that standardized measures of value begin to matter. One of the exchange theorists' most important insights concerns the way societal norms function as primitive measuring rods that make indirect social exchange possible. ${ }^{34}$

Thus, one not only needs a contextual analysis and a study of the historical background but one also must be familiar with the societal background of norms. This has the important consequence that any technological, political, cultural, or normative development that improves the efficacy of certain resources in affecting outcomes can, in turn, become a target for attempts to gain influence. Therefore, two strategies are possible to improve one's potential power in a given situation: to cause either a quantitative improvement

32. See ibid.; and Baldwin, Economic Statecraft, p. 285.

33. Roderick Martin, The Sociology of Power (London: Routledge and Kegan Paul, 1977), p. 29.

34. David A. Baldwin, "Power and Social Exchange," in Baldwin, Paradoxes of Power, p. 125, italics original. 


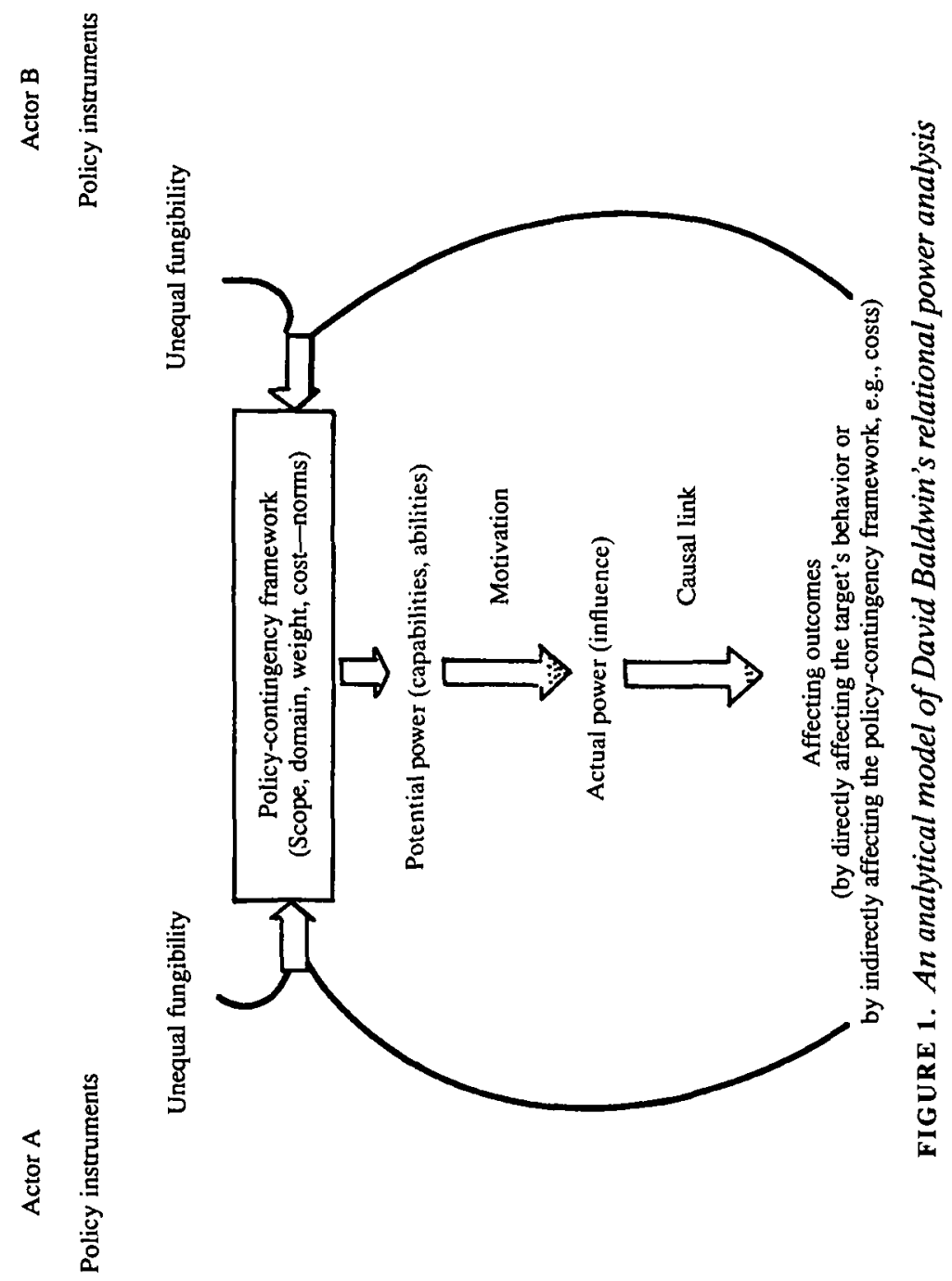


of the relevant situational power resources or a change in the environment that defines the situationally relevant power resources. The latter is exactly what Krasner defines as metapower. Thus, the intentional agenda-setting that Krasner tried to integrate into realist power analysis can indeed be coherently accounted for within the methodology used by neorealists.

Baldwin's approach (as synthesized in Figure 1) will serve as the reference point for discussing the other two meanings of structural power.

\section{Power as a dispositional concept: nonintentional power and the limits of neorealist power analysis}

The second distinct meaning of structural power is still conceived at the level of agents but refers to an action's unintended (and sometimes unconscious) effects. This meaning cannot be simply grafted onto a neorealist understanding of power, because the latter links power to intentionality. It can be linked to a dispositional concept of power. This section will show how the second meaning of structural power can successfully supplement Krasner's concept. In the final part of the article, dispositional approaches of this sort will be shown to be unsatisfactory because their concept of structure is too limited.

Strange's work illustrates this notion of structural power as "nonintentional power." She developed her concept in opposition to the literature of American hegemonic decline. ${ }^{35}$ The expression of decline is chosen on purpose. One of the theses of the hegemonic stability theory states that a declining hegemonic power presages a declining provision of the international public good. For Strange, the decline school is based on a fallacious inversion of this thesis, namely, that the declining provision of international public goods would indicate the declining power of the hegemon. She tries to show that the United States is not unable but just unwilling to provide, or help to provide, basic functions of a global political economy. Her concept of structural power is crucial to pointing to the global reach of a so-called transnational empire with the United States at its center.

She uses structural power to refer to the increasing diffusion of international power, in both its effects and its origins, due to the increasing transnationalization of nonterritorially linked networks. Structural power is, on the one hand, a concept similar to Krasner's intentional metapower: the ability to shape the security, financial, productive, and knowledge structures. ${ }^{36}$ Here, power is

35. The reference definition of hegemonic stability theory has been given by Robert Keohane, "The Theory of Hegemonic Stability and Changes in International Economic Regimes, 19671977," in Ole R. Holsti, Randolph M. Siverson, and Alexander L. George, eds., Change in the International System (Boulder, Colo.: Westview Press, 1980), pp. 131-62. Yet, it seems too much tailored for his regime approach, neglecting the collective-good argument. For a convincing argument, see Duncan Snidal, "The Limits of Hegemonic Stability Theory," International Onganization 39 (Autumn 1985), pp. 579-614, and especially p. 581.

36. Susan Strange, "International Political Economy: The Story So Far and the Way Ahead," in W. Ladd Hollist and F. LaMond Tullis, eds., An International Political Economy (Boulder, Colo.: Westview Press, 1985), pp. 13-25, and, in particular, p. 15. 
structural because it has an indirect diffusion via structures. On the other hand, Strange understands power as structural because it refers to the increasingly diffused sources and agents that contribute to the functioning of the global political economy ${ }^{37}$ Taken together, the provision of global functions appears as the result of an interplay of deliberate and nonintentional influence of decisions and nondecisions made by governments and other actors. ${ }^{38}$ To Strange, then, the international system appears as if run by a "transnational empire," whose exact center is difficult to locate because it is not tied to a specific territory, but whose main base is in the United States. ${ }^{39}$ In other words, even though actors in the United States might not always intend or be able to control the effects of their actions, the international structures are set up in a way that decisions in some countries are systematically tied to and affect actors in the same and other countries.

The September 1992 crisis of the European Monetary System shows that structural power also exists outside the United States. German reunification led to inflation that was controlled only partly through a reversal of prior fiscal policies. The German Bundesbank then exported the problem via higher interest rates. These higher rates helped to trigger a speculative attack on the British pound and the Italian lira. This, in turn, involved so much money moving across borders that central banks quickly judged interventions to be too costly for both the inflating DM and the deflating monetary reserves of the attacked currencies. Thus, one basic reason for these effects is a specific policy mix decided by the German government together with the strained social consensus in Germany. Germany's position and sheer "weight" within the European system gives it the privilege of avoiding some of the painful adjustments others are facing. It manages a transnational currency as if it were a national one..$^{40}$ Yet, for particular actors, many of what appear to be purely domestic decisions in fact significantly affect other actors, whether intentionally or not. Actors in Germany have a great deal of nonintentional or non-

37. For a concise presentation of recent power concepts with a similar analysis of Strange's approach, see Bertrand Badie and Marie-Claude Smouts, Le retoumement du monde: Sociologie de la scène internationale (The world's overturning: Sociology of the international scene) (Paris: Presses de la Fondation Nationale des Sciences Politiques \& Dalloz, 1992), pp. 148-56.

38. See the following works by Susan Strange: "What About International Relations?" in Susan Strange, ed., Paths to International Political Economy (London: George Allen \& Unwin, 1984), pp. 183-97, and especially pp. 190-91; and States and Markets: An Introduction to International Political Economy (London: Frances Pinter, 1988), where this notion is developed most fully. For the empirical analysis of U.S. nondecisions, see Casino Capitalism (London: Basil Blackwell, 1986), chap. 2.

39. Susan Strange, "Toward a Theory of Transnational Empire," in Czempiel and Rosenau, Global Changes and Theoretical Challenges, pp. 161-76.

40. With regard to the management of the U.S. dollar, this critique has a longer tradition. For one example, see Raymond Aron, Les dermières années du siècle (The century's last years) (Paris: Julliard, 1984), p. 44. It is important to note that the power to avoid or to export adjustments can, in the long run, undermine the very base of "national" power. This argument is most thoroughly made in David P. Calleo's work; for example, see The Imperious Economy (Cambridge, Mass.: Harvard University Press, 1982); and Beyond American Hegemony: The Future of the Westem Alliance (New York: Basic Books, 1987). See also Dieter Senghaas, Friedensprojekt Europa (Peace project Europe) (Frankfurt/Main: Suhrkamp Verlag, 1992), p. 55. 
conscious power to which all the other participants in the international game must nevertheless adapt their behavior (typically in worst-case scenarios). Or, to use an image of Pierre Hassner's for the description of a condominium: it does not make any difference to the trampled grass if the elephants above it make love or war. This structural power is underrated if one analyzes power only in cases of specific contests in which different intentions clash.

The remaining part of this section will analyze the two implicit claims of this form of structural power. First, it will show that economic approaches can include the study of nonintentional effects but cannot include them in the concept or analysis of power itself, instead referring to these effects as either random effects or simply good or bad luck. Second, nonintentional power can, however, be accounted for by a methodological individualist position. Strange's approach is based not on a relational but on a dispositional concept of power.

For the exclusion of nonintentional effects from the concept and analysis of power, we return to Baldwin's framework as the choice-theoretical reference point. Baldwin tries to elaborate a policy-oriented, manipulative, and thus agent-focused theory of power. Yet, his power concept has been pulled increasingly toward a type of reasoning that focuses on outcomes and not on a manipulative agent. In other words, Baldwin seems to be torn because of a conceptual dilemma that is also applicable to Krasner's concept: his conceptual approach to power expands to include all effects that influence outcomes, whereas his actual policy analysis argues for a power concept that is limited to the intentional agent. We could describe this in William Riker's terminology as a dilemma in which Baldwin's aim is the study of statecraft through a "recipelike" concept of causality (and power), while his conceptual analysis pulls him toward a "necessary and sufficient" kind of causality. ${ }^{41}$ Whereas the former focuses on manipulative techniques, the latter aims at a full explanation of what affects the outcome, whether overtly or covertly. According to Baldwin, "although Riker may be correct in asserting the superiority of the latter concept of causality for some types of science, the former concept is more useful in the policy sciences and will therefore be employed here." 42 Yet, as Riker says, "The more profound difficulty with recipe-causality, however, is that it takes as fixed all relevant variables, except the manipulative one.... If a non-manipulative variable in the antecedent condition does have a relation to the effect, then it must be involved in the cause, even though recipe-causality does not admit it." ${ }^{, 43}$ In his attempt to preserve power as an operationalizable causal concept, Baldwin incorporates more and more items to account for the exact contextual assessment of manipulative techniques; yet, he avoids provid-

41. William H. Riker, "Some Ambiguities in the Notion of Power," in R. Bell, D. V. Edwards, and R. H. Wagner, eds., Political Power: $A$ Reader in Theory and Practice (New York: Free Press, 1969), p. 116. The recipelike concept is defined as the production of effects through the manipulation of nature.

42. Baldwin, Economic Statecraft, p. 26.

43. Riker, "Some Ambiguities in the Notion of Power," p. 116. 
ing the full account of the causality chain toward which this very extension pulls his analysis. To cite Riker again:

The difference between the two kinds of causality is, like the difference among definitions of power, a difference in orientation toward outcomes. In recipe-like causality, the full explanation of the effect is not the problem. Rather the problem is to explain how the effect can be made to occur. If no manipulative technique is available, cause may be non-existent. By contrast, in the necessary and sufficient condition kind of causality, the center of attention is on the effect rather than on manipulative techniques. Here the full explanation of outcomes is at stake. Hence, cause cannot be non-existent, although it can be unidentified. ${ }^{44}$

The choice of a recipe concept of power deprives the analysis of those causal factors that cannot be linked or reduced to the agent's conscious manipulation of the resources at hand. Power as the production of unintended effects is not captured because it falls outside the causal link between A's intention and B's changed behavior. The only exception that the pluralist power literature accepts, the rule of anticipated reaction, is a case of imputed intentions, but intentions nevertheless. Therefore, by reducing the analysis of power to the establishment of a causal chain from A's intention to the outcome, a choice-theoretical approach cannot theoretically incorporate the idea of power as unintended effects into the concept of power.

This does not mean that these unintended effects are forgotten in a choice-theoretical analysis. Riker's important point consists of showing that by sticking to a specific mode of explanation, these unintended effects must be dealt with either as environmental constraints or as purely random phenomena. Since manipulative power entails the idea that one can change the course of affairs, those excluded items appear as a kind of fate against which even the most powerful actors remain powerless. The far-reaching consequence of this apparently innocent methodological move lies on the level of political action and responsibility. If we have to face fate, then there is nothing to do. Yet, Strange's insistence on unintended effects attempts to show that agents could make a difference if they wanted. Her widened concept of power aims at shedding light on the possibilities for change and on the (political) responsibility for nonmanipulative effects that a limited concept of power must disregard.

Concepts of structural power suggest that this widening of the concept needs to integrate a structural element into the power concept. In fact, this is not true. One can leave intentionality out of an agent-based power concept, but it is then necessary to relax the empiricist assumptions, the interactionist approach, and the general causal analogy. Thus, the analytical chain starts not from an agent's intentions but from basic actions. That this conceptualization is not just a theoretical possibility can be shown by referring to a recent redefinition of power in exactly these terms. 


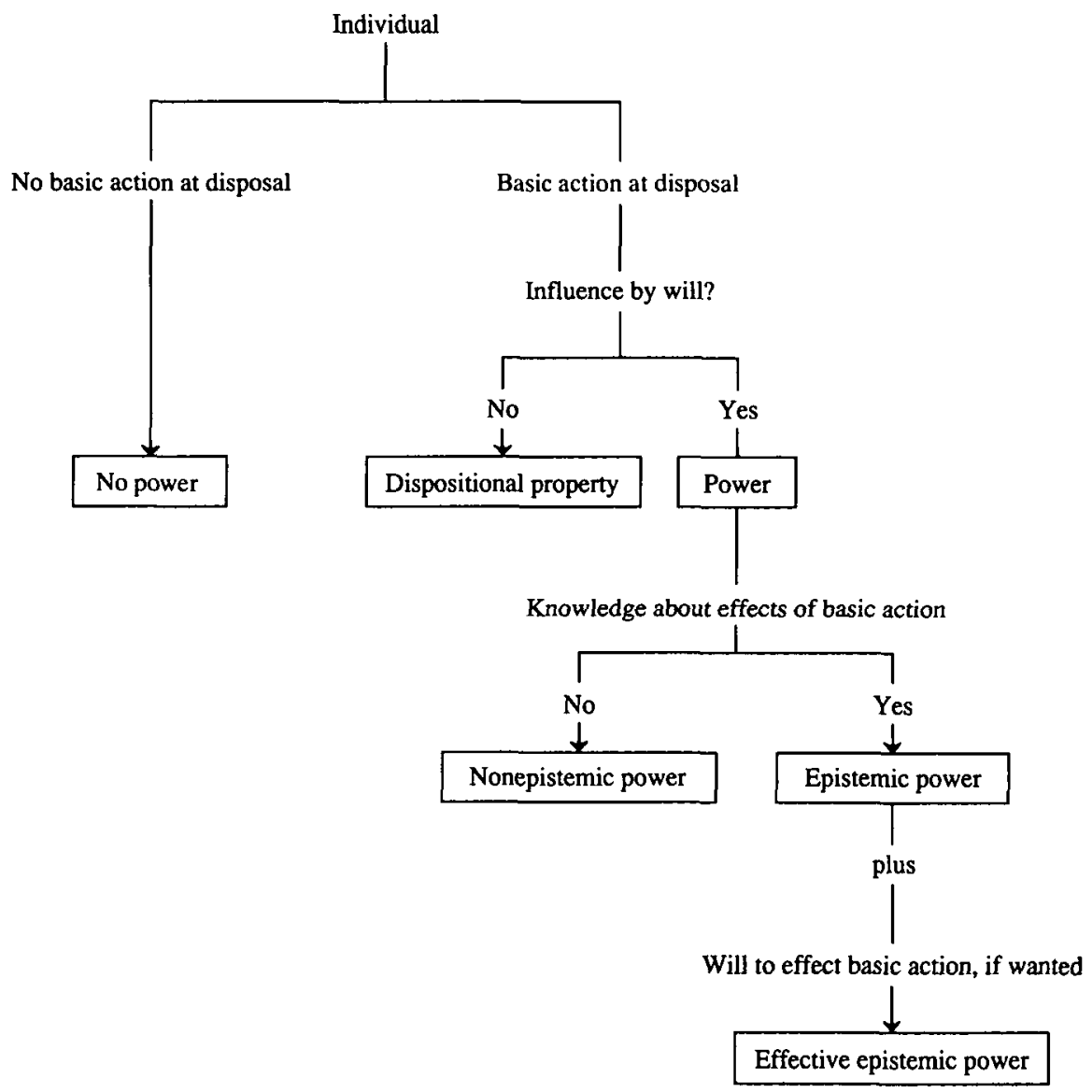

FIGURE 2. Morriss's dispositional conceptualization of power

Peter Morriss bases his analysis on a concept of power that he distinguishes from mere influence by pointing to the profound dispositional character of power: power, to him, refers to a capacity, ability, or dispositional property: "So power, as a dispositional concept, is neither a thing (a resource or vehicle) nor an event (an exercise of power): it is a capacity." 45 Since power is defined as an ability, every basic action, controlled by will, at the disposal of an actor can be considered as power. The capacity to influence by will is thus a criterion to distinguish power from a (dispositional) property.

Morriss goes on to distinguish, as shown in Figure 2, three categories of

45. Peter Morriss, Power: A Philosophical Analysis (Manchester, U.K.: Manchester University Press, 1987), p. 19; emphasis original. On pages 15-18, Morriss criticizes the pluralists for their excessive empiricism in requiring the actual exercise of power as a condition for its existence. He calls this the "event-fallacy." For a discussion of both fallacies in IR and IPE, see Daniel Garst, "Thucydides and Neorealism," International Studies Quarterly 33 (March 1989), pp. 3-27, and, in particular, pp. 20-22. 
ability. ${ }^{46}$ Since this conceptualization of power is based on "effecting," Morriss disposes also of a category for nonintentional power. "Nonepistemic" abilities are those that are effected in an uncontrolled way, such as when agents are unaware of their capacities and their consequences or they choose the wrong basic action for the intended outcome. This category is able to take account of Strange's idea of nonintentional power, which looks at power from the "receiving side." Morriss shows that whenever "we want to work out what people might do to us, it is non-epistemic power we are concerned with." 47

This stress on mere capacities and not their exercise seems at first hand close to the traditional power analyses in IR. The important difference is that those approaches posited a direct link between the control of outcomes and capacities, whether they are implemented or not. Strange's structural power looks at power from the point of view of the diffused power effects and stresses the uncontrolled consequences of power actions. ${ }^{48}$

The major difference of such a dispositional approach from an interactionist rational-choice approach is that these consequences are part of the power assessment and are not just random. This contradicts approaches like Klaus Knorr's, for instance, who explicitly and coherently refuses to accept such a form of nonintentional power. Knorr dismisses François Perroux's concept of dominance, which is close to Strange's structural power, as purely incidental and therefore irrelevant for power analysis. ${ }^{49}$ This exclusion of nonintentionality privileges the manipulative actor's (or power holder's) view and leaves the analysis of power with a specific blind spot, namely, the tacit power of the strong. If neorealism goes on following this route, it is to be expected that criticisms of the kind implicit in different structural power concepts will continually reappear. Hence Baldwin acknowledges, without further discussion, that "concepts of power that allow for the possibility of unintended influence may be more useful to the student of dependency and autonomy than other power concepts." 50

\section{Power as a structural/intersubjective concept: impersonal power}

The last of the three meanings of structural power and related concepts can be generically described as "impersonal power" because the origin of the

46. Morriss, Power: A Philosophical Analysis, p. 54.

47. Ibid., p. 54.

48. Coming to the second side of her power approach, the diffusion not of the effects but of the origins of power, Strange does, however, individualize a privileged actor, the "international business civilization." In other words, nonintentional power is very unevenly distributed throughout the international power structure. See Susan Strange, "The Name of the Game," in N. Ritopoulos, ed., Sea-changes: American Foreign Policy in a World Transformed (New York: Council of Foreign Relations Press, 1990), pp. 238-74.

49. Klaus Knorr, Power and Wealth: The Political Economy of Intemational Power (London: Macmillan, 1973), pp. 77-78.

50. Baldwin, "Interdependence and Power," p. 205. 
produced effect is not located at the level of actors. Here, two different conceptualizations can be distinguished. The first could be described as a positional concept that focuses on the impersonal bias of international relations, which systematically gives an advantage to certain actors due to their specific positions or roles in the international system. The second stresses the link between knowledge and power, arguing that power requires prior intersubjective recognition. Both approaches explicitly attempt to abandon the underlying choice-theoretical mode of explanation. These concepts, too, are unsatisfactory because they tend to overload and thus render incoherent the single concept of power. This section will present the two approaches; the next section takes their insufficiencies as the basis for developing a different power analysis derived from a dyad of concepts.

The first more positional approach to power has been introduced by James Caporaso. He accepts the centrality of power, yet gives it a double twist in order to incorporate the link between the global political economy and less developed countries' economic and political development. The focus on "bargaining power in asymmetrical interdependence" is considered insufficient. ${ }^{51} \mathrm{He}$ acknowledges that dependence is, on the bargaining level, no criterion for a qualitative differentiation of less developed countries. ${ }^{52}$ Yet, he integrates the "second face" of power, derived from Bacharach and Baratz, to save a concept of dependency. This is called structural power. Implicitly, he also repeats an ambiguity that can be found in the work of Bacharach and Baratz. ${ }^{53}$ Their nondecision making can mean both the inherent bias of any organization that benefits some more than others (nondecisions as "structural bias") and the conscious manipulation of the bias to affect outcomes in an advantageous way (nondecisions as "antedecisions"). Caporaso refers to the latter in his definition of structural power as "the ability to manipulate the choices, capabilities, alliance opportunities, and pay-offs that actors may utilize." 54 This is in line with Krasner's concept of metapower. Yet, he also speaks of "the social structuring of agendas [that] might systematically favor certain parties," which is definitely an impersonal concept. ${ }^{55}$

51. James A. Caporaso, "Introduction to the Special Issue on Dependence and Dependency in the Global System," and "Dependence, Dependency, and Power in the Global System: A Structural and Behavioral Analysis," Intermational Organization 32 (Winter 1978), pp. 1-12 and 13-43, respectively. The quotations are from pages 4 and 28 and allude, of course, to Keohane and Nye's Power and Interdependence.

52. Ibid., pp. 2 and 18. This point has been most elegantly made by Sanjaya Lall, "Is 'Dependence' a Useful Concept in Analysing Underdevelopment?" World Development 3 (November-December 1975), pp. 799-810.

53. This ambiguity has been largely neglected in the literature. For an exception, see Geoffrey Debnam, The Analysis of Power: A Realist Analysis (London: Macmillan, 1984), p. 24.

54. Caporaso, "Introduction to the Special Issue on Dependence and Dependency in the Global System," p. 4.

55. Caporaso, "Dependence, Dependency, and Power in the Global System," p. 33. In more recent writings, Caporaso retreats slightly from this latter position. He retains the basic division between relational (agent-based) and structural power approaches. Yet, together with Stephen Haggard, he now concludes that these forms of power are not necessarily competing categories: 
In a similar vein, Gill and Law try to overcome the dominant behavioral power paradigm in IR and IPE by a concept of structural power that is said to capture better the indirect forms of power. ${ }^{56}$ Explicitly following Lukes, they begin by distinguishing three dimensions of power: overt, covert, and structural. ${ }^{57}$ Later, they introduce a direct/indirect distinction. Although they are not explicit, they seem to rely on individual action as the distinctive criterion. Thus, overt and covert power are linked to agents' decisions and nondecisions in pursuing their interests, whereas structural power refers to "material and normative aspects, such that patterns of incentives and constraints are systematically created." 58

Their "impersonal material setting" is nearly synonymous with the functioning of markets. Through markets, the structural power of capital is exercised..$^{59}$ The state-market nexus becomes the very center of the analysis. ${ }^{60} \mathrm{Gill}$ and Law focus on the relationship between the political organization of the global political economy into nation-states and the power of capital. On the one hand, international anarchy enhances capital's bargaining position, allowing it to play one country against another; on the other hand, national sovereignty can reduce capital's power through statist intervention, such as welfarism, mercantilism, and the public sector. The absence of a world government is as much a structural prerequisite for the power of capital as a limitation to the potentially global reach of market-economic activities. Hence, in the material part of their approach, the logic of the market overtakes the balance of power or regimes as the central and slightly mechanistic explanatory variable, which provides the basic causality and predictive virtue. ${ }^{61}$

However, Gill and Law also stress a second, normative aspect of structural power/hegemony. This is the basic link between structural power and Antonio Gramsci's analysis of hegemony, which, following the work of Robert Cox, they

they both refer to (different kinds) of resources that affect outcomes understood as bargains (see their "Power in the International Political Economy"). For a critique of this argument, see the third part of this article.

56. See in particular two works by Stephen Gill and David Law: The Global Political Economy (New York: Harvester, 1988); and "Global Hegemony and the Structural Power of Capital," Intemational Studies Quarterly 33 (December 1989), pp. 475-99.

57. For a similar account, based on Steven Lukes's three dimensions, see Keith Krause, "Military Statecraft: Power and Influence in Soviet and American Arms Transfer Relationships," International Studies Quarterly 35 (September 1991), pp. 313-36.

58. Gill and Law, The Global Political Economy, p. 73.

59. For the definition of capital, see Gill and Law, "Global Hegemony and the Structural Power of Capital," pp. 480-81. Note that the terms "power of markets" and "structural power" are sometimes used interchangeably; see Gill and Law, The Global Political Economy, p. 97.

60. The state-market nexus "politicizes" (in an Eastonian way) international economic relations. The analysis is centered around the two competing authoritative allocation mechanisms (for values or resources) that exist: states and markets. See Ernst-Otto Czempiel, Internationale Politik: Ein Konfliktmodell (International politics: A conflict model) (Paderborn, Germany: Schöningh, 1981); and Ernst-Otto Czempiel, "Internationalizing Politics: Some Answers to the Question of Who Does What to Whom," in Czempiel and Rosenau, Global Changes and Theoretical Challenges, pp. 117-34.

61. Gill and Law, "Global Hegemony and the Structural Power of Capital," p. 485. 
want to transfer to the international level. True, no realist would dispute the derivation of norms from power relations, the conservative bias of law in the hands of the ruling group, the importance of the normative setting for specific historic global political economies (regimes of accumulation), or, finally, the anticipated ruling of power where its overt demonstration is not needed. ${ }^{62}$ However, the Gramscian approach derives the ruling ideology from a class analysis, that is, from the sphere of production. ${ }^{63}$ It goes beyond crude materialism by pointing to the fact that the ruling elite can co-opt part of the ruled into a "historic bloc," which makes orthodox revolutionary politics impossible. The research program of this power approach consists of finding the new transnational historical bloc and the way its (neoliberal) discourse and practice suborn dependent classes and preempt their opposition.

This latter point, in particular the consensual aspect of power, has been developed by Ashley in the second impersonal conceptualization of power as power/knowledge. The consensual aspect is traditionally handled through the concept of legitimacy that, in the usual reading of Max Weber, distinguishes between power (Macht) and authority/rule (Herrschaft). Herrschaft requires legitimacy, that is, a form of internal acceptance by the power addressees. ${ }^{64}$ The poststructuralist twist can be seen in the metatheoretical location of phenomena of power. This means that consensus is conceptualized not only in an agent's recognition but also as produced and reproduced outcomes of rituals and discourses that are not intentionally effected by particular actors. Legitimacy understood as the result of a social contract is an insufficient concept to account comprehensively for consensus and governance..$^{65}$ In this formulation, the consensual aspect of power entails, but means certainly something more than, a shift of focus to a kind of Weberian approach wrapped in a Gramscian blanket. ${ }^{66}$ This approach has, then, its specificity not only in the actual meaning

62. On the first point, see Hans J. Morgenthau, Politics Among Nations (New York: Knopf, 1947), pp. 342ff; and on the second, see Kenneth Waltz, "International Structure, National Force, and the Balance of Power," reprinted in James Rosenau, ed., Intemational Politics and Foreign Policy: A Reader in Research and Theory (New York: Free Press, 1969), pp. 304-14, at p. 309. Note in this context Antonio Gramsci's interest in the Italian Realist tradition (Niccolò Machiavelli, Gaetano Mosca, Vilfredo Pareto) in Antonio Gramsci, Noterelle sulla politica del Machiavelli: Quaderno 13 (Notes on Machiavelli's politics: Notebook 13) (Turin: Einaudi, 1981).

63. Cox insists on the rooting of hegemony in social forces, to avoid repeating Machiavelli; see Robert Cox, "Gramsci, Hegemony, and International Relations: An Essay in Method," Millennium 12 (Summer 1983), pp. 162-75, and especially p. 164.

64. Norberto Bobbio, "La teoria dello stato e del potere" (The theory of the state and of power), in Pietro Rossi, ed., Max Weber e l'analisi del mondo (Max Weber and the analysis of the world) (Turin: Einaudi, 1981), pp. 215-46, and, in particular, p. 226.

65. Michel Foucault, "Corso del 14 gennaio 1976," in Michel Foucault, Microfisica del Potere: Interventi Politici (The microphysics of power: Political interventions) (Turin: Einaudi, 1977), p. 188.

66. For the stress on Herrschaft, see Ulrich Albrecht, Intermationale Politik: Einfühnung in das System internationaler Herrschaft (International politics: Introduction into the system of international rule) (Munich: Oldenbourg Verlag, 1986). For the Gramscian wording, see Bradley S. Klein, "Hegemony and Strategic Culture: American Power Projection and Alliance Defence Policies," Review of Intemational Studies 14 (April 1988), pp. 133-48, and, in particular, p. 134. 
given to power but also in the realm to which it is applied. It does not analyze power in IR and IPE as reflected in its discourse but the power of precisely this discourse. The poststructuralist critique aims at that level at which such power practices are concealed, that is, the metatheoretical level which underlies realist analysis and consequently its deliberate policies. ${ }^{67}$ The realist discourse is attacked as a power practice itself.

Ashley expands what one could call a "communicative" approach" ${ }^{68}$ to a Foucauldian genealogical power conceptualization. His genealogical attitude can be summarized as an attempt to reveal the power practices that bind, conquer, and administer social space and time, that is, the emergence of "disciplines." 69

Crucial for this understanding of power is a specific concept of practices that includes not only interactive influence attempts but also rites, routines, and discourses. Thereby one disposes of an intersubjective level of analysis different from an objectified or even determinist structure as well as from an intentional agent. Rites and routines are not just a constraint or a resource for agents; they also empower agents. In this approach it makes sense to speak of the power of rites. According to David Kertzer, "The power of the rite is based in good part on the potency of its symbols and its social context.... People's emotional involvement in political rites is certainly a key source of their power."

There are two ways in which rites can be linked to power. First, they can obviously be used as a means or source of an intentional influence attempt. A recent example is the Western propaganda that modeled Saddam Hussein as a modern Adolf Hitler. The "powerful" analogy constituted a means to stimulate widespread approval of U.S. foreign policy in those European circles that usually are rather critical of it. Second, rites can also empower agents. In this case, the power of rites is impersonal, because it does not originate in an actor. But at the same time, it is not objective or natural-like the power of hurricanes, for instance-because rites are not powerful independent of agents. The symbol of Munich can be intentionally invoked by actors, but it keeps a particular hold on Western political discourse and thus also on policymaking since 1938 . Its power is constantly renewed or shaken by more recent applications. The rallying power of a national flag can be used by politicians, but the symbol escapes their control; it "governs" independently of

67. The most radical power critique at the metatheoretical level is the poststructuralist branch of feminism. See Anne Sisson Runyan and V. Spike Peterson, "The Radical Future of Realism: Feminist Subversions of IR Theory," Altematives 16 (Winter 1991), pp. 67-106, and, in particular, pp. 75-76 and 97-98.

68. See Richard Little, "Deconstructing the Balance of Power: Two Traditions of Thought," Review of Intemational Studies 15 (April 1989), pp. 87-100; and Friedrich Kratochwil, "Regimes, Interpretation, and the 'Science' of Politics," Millennium 17 (Summer 1988), pp. 263-84, and especially p. 272.

69. Richard Ashley, "The Geopolitics of Geopolitical Space: Toward a Critical Social Theory of International Politics," Alternatives 12 (October 1987), pp. 403-34, and especially p. 418.

70. David I. Kertzer, Ritual, Politics, and Power (New Haven, Conn.: Yale University Press, 1988), pp. 179 and 180. 
particular intentions, albeit not independently of the practices and the meaning given to it by the group of actors involved.

Ashley derives such a form of impersonal power from the work of Pierre Bourdieu. Fundamental here is Ashley's introduction of Bourdieu's concept of "doxa." Bourdieu distinguished doxa both from orthodoxy (a kind of established truth or common wisdom) and from heterodoxy (orthodoxy's official contender). The two latter concepts refer to the universe of open discourse and argument and depend on each other. Doxa, on the other hand, refers to the self-evident background of the established order on which the contest between orthodoxy and heterodoxy is articulated. Even though the realm of doxa is necessary to set the stage, its contingency is not acknowledged: "Every established order tends to produce the naturalization of its own arbitrariness." Writes Bourdieu:

In the extreme case, that is to say, when there is a quasi-perfect correspondence between the objective order and the subjective principles of organization (as in ancient societies) the natural and social world appears as selfevident. This experience we shall call doxa. ... The instruments of knowledge of the world are in this case (objectively) political instruments which contribute to the reproduction of the social world by producing immediate adherence to the world, seen as self-evident and undisputed, of which they are the product and of which they reproduce the structures in a transformed form.... The theory of knowledge is a dimension of political theory because the specific symbolic power to impose the principles of the construction of reality-in particular, social reality, is a major dimension of political power. ${ }^{71}$

The domain of doxa represents a system of normalized recognition through continuous practice that ceases to work (and incidentally also to exist) exactly at the moment when conscious legitimation is needed. Thus, Ashley locates impersonal empowering explicitly at an intersubjective level, where knowledge is constituted and acting and thinking space defined. There roles and practices are constructed, and they then operate systematically and nonintentionally, that is "naturally," not only to exclude issues from the agenda but also to prevent the very definition of such issues and their possible solutions. Ashley writes that "the political power of hegemony ... is neither a 'power over' other actors nor a 'power to' obtain some consciously deliberated future end among ends. The power of hegemony resides precisely in the capacity to inhabit a domain of doxa and to competently perform the rituals of power naturalized therein." 72

We can use a critique of neorealism as an illustration of Ashley's "dissident"

71. Pierre Bourdieu, Outline of a Theory of Practice (Cambridge: Cambridge University Press, 1977), pp. 164 and 165.

72. Richard Ashley, "Imposing International Purpose: Notes on a Problematic of Governance," in Czempiel and Rosenau, Global Changes and Theoretical Challenges, pp. 251-90, and, in particular, p. 269. 
power analysis. The latter would attempt to counter the closing-off procedures that the move toward neorealism "effected" in the face of the increasing dissolution of the discipline's boundaries in the 1970s. The qualitative difference between international and domestic politics, that is, anarchy and sovereignty, already had been attacked by the older behavioral claim that methodologically the study of internal and external policies is alike, by the rising importance of transnational actors that undermine the concept of sovereignty, and by bureaucratic politics that question the notion of a unified or rational actor. Waltz's reformulation of realism restored the categorical dichotomy and thus provided the discipline with a defining boundary. Waltz's defense comprised the off-loading of transnational and infranational phenomena into the area of foreign policy analysis (hence political science), thus preserving a systemic realism. Its effect, or its power, derived from its ability to rescue IR as a respectable and legitimate discipline-respectable through its commitment to economic methodology and legitimate because it could not be "reduced" to any other field in the social sciences' division of labor. Waltz's neorealism was so "powerful" not because its parsimonious balance-of-power theory could uncover more things about the real world than we knew before but because it mobilized the scientific community's longing for a paradigmatic core. By preempting specific heterodox views, Waltz's discourse prepared the ground on which the legitimate debate of the discipline between neorealism and neoinstitutionalism could take place. In other words, it did not provide a convincing answer to the anomalies of the discipline, but it was successful in mobilizing established conceptions of the legitimate way to approach them. ${ }^{73}$

Consequently, this strong metatheoretical outlook of poststructuralism is at once the historical symptom of a discipline in crisis and the necessary outlook of an explanatory framework that seeks to disclose knowledge trapped in the positivist rational-choice discourse of neorealism.

Since the authors of this third meaning of structural power have themselves departed explicitly from the choice-theoretical basis of neorealism, what is at issue here is not whether these structural approaches of power can be integrated into neorealism; rather it is whether they are internally coherent and whether their insights are necessarily linked to a power analysis.

\section{A power analysis with a dyad of concepts}

This final section deals with the fallacies inherent in possible overextensions of the concept of power and proposes a solution that distinguishes between two concepts, power and governance, that must be put together in a comprehensive power analysis.

73. See Kenneth Waltz's works, Theory of International Politics (Reading, Mass.: AddisonWesley, 1979); and especially "A Response to My Critics," in Keohane, Neorealism and Its Critics, pp. 322-45. In the latter work, Waltz does not respond to the move to the metatheoretical level on which Ashley's critique is pitched. 


\section{Overload fallacies of structural power}

The three following fallacies illustrate the impossibility of limiting power phenomena to a single concept at either the agent or the structural level. The first fallacy is trying to extend an agent concept to cover all power phenomena. This problem is linked to the concept of human agency itself. Following Dennis Wrong, the fallacy consists of not distinguishing between intentional and nonintentional action. By failing to make this distinction (and by not reserving the exercise of power for intentional and responsible action), one inevitably makes the effect of power coincide with human action. For this reason Wrong limits the concept of power to the capacity to produce intended effects including unintended, but foreseen side effects. ${ }^{74}$ Unforeseen effects are considered important for any analysis in social science and part of a more general concept of influence but are not generally considered relevant to the concept of power as such. Yet, foresight does not seem to be a good criterion for the distinction of power relations from general agency because it would result in giving too much emphasis to the viewpoint of those who exercise power as opposed to those who have to bear its consequences. ${ }^{75}$ Morriss's argument remains valid at this point; if one conceives of power as a way of "effecting," as Wrong also does, then unintended effects must be included. ${ }^{76}$

Thus, the initial problem remains: how to avoid collapsing all power phenomena into agency? Lukes, aware of this difficulty and the shortcomings of intentionalist approaches, starts by saying that the "effecting" must be considered significant for a particular reason (and is therefore contestable). His distinctive criterion is not intention and its link to responsibility but "interest furthering."

Yet, this approach points to the second possible fallacy of structural power as impersonal empowering: pluralists refuse it because it would entail the "power-as-benefit fallacy." Deducing power from positive effects produces the anomaly of the free rider, whose interests are furthered by the system but who remains nevertheless at its mercy. It seems odd to describe the free rider as necessarily powerful. ${ }^{77}$

Even more carefully developed individualist approaches suffer from this

74. Dennis H. Wrong, Power: Its Forms, Bases, and Uses, 2d ed. (Oxford: Basil Blackwell, 1988), pp. 3-5.

75. J. M. Barbalet, "Power, Structural Resources, and Agency," Current Perspectives in Social Theory, vol. 8, 1987, pp. 1-24, and, in particular, p. 6.

76. One of the reasons for the reluctance to incorporate nonintentional power is the relationship between the concepts of power and responsibility in agent-oriented theories. It seems, however, to be going too far to conclude that since it is difficult to assess responsibility in cases where unintended effects have been produced, such effects must necessarily be excluded from power analyses. The extent of responsibility must be judged case by case. For both the intended and unintended consequences of action, the capacity to effect an outcome (i.e., power) is a necessary but not sufficient condition for an actor's responsibility.

77. Polsby, Community Power and Political Theory, p. 208. 
shortcoming. Morriss, for instance, explicitly attempts to include such impersonally produced effects. For this purpose, he introduces the notion of passive power to account for the cases where we "don't want to differentiate between people who do get something and people who can get it, but we want to distinguish these people from those who cannot get it." Morriss then defines passive power as being "passive in both senses: no choice is involved because you could not intervene to prevent the outcome occurring; it would come about in spite of anything you might do." 78 This illustrates the "benefit fallacy": deduce power from rewards. ${ }^{79}$ Morriss accepts the charge, yet considers it beside the point:

There is no need to claim that because someone benefits she must cause her good fortune, nor that she can control it. All one need do is note that a status quo that systematically benefits certain people (as Polsby agrees it does) is relevant in itself. ... Yet if the social system performs in such a way as systematically to advantage some individuals or groups, it certainly seems odd not to take account of this. ${ }^{80}$

I agree that it would be a great mistake in an empirical analysis of a specific outcome to neglect how the structural bias on the normative, institutional, or economic level affects the very way power relations are built up, conceived, understood, and decided. But why must we take account of it by integrating it into the concept of power as such, especially if we refuse, as Morriss does, the argument of power as a subcategory of cause? Impersonal effect or structural bias may be part of any power analysis, but it cannot be part of the concept of power if the latter is actor-based, as in the case of the pluralists' relational conception or Morriss's dispositional one.

The third fallacy represents a mirror image of the first one, namely, a form of structural reductionism. All the approaches considered so far take into account the policy-contingency framework, or whatever the authors prefer to call the contextual part of their analyses. The notion of impersonal power seems to require a founding outside the agent, not within the person's intention (in the narrow behavioral approach) or action (in the wider individualist approach). This has provoked major critiques. By not sufficiently stressing the fundamental agent reference of power, the criticism runs, the concept of power becomes either synonymous with structural constraint, thus rendering structural power a contradiction in terms, or else it becomes a rather amorphous all-encompassing concept like social control. ${ }^{81}$

This critique stems from writers whose concept of power rests on a rather

78. Morriss, Power: A Philosophical Analysis, p. 100. In both quotations the emphasis is original.

79. Brian Barry, "The Uses of 'Power,' " in Barry, Democracy, Power, and Justice, p. 315.

80. Morriss, Power: A Philosophical Analysis, pp. 105-6.

81. For the first charge, see Steven Lukes, Essays in Social Theory (New York: Columbia University Press, 1977), p. 9; and for the second, see Wrong, Power: Its Forms, Bases, and Uses, p. 252. 
strong concept of agency, as, for instance, in the agency assumptions of rational-choice theories (desires, beliefs, preferences, rationality, choices) or, in a different vein, as in the case of Lukes, for whom power becomes attached to personal autonomy and the moral discourse of freedom and justice. Both approaches retain, on the other hand, a very thin concept of structure. Obviously, if structures are just seen as constraints, then structural power is a contradiction in terms. But this is due not to a supposedly inherent agency reference for power phenomena but to an insufficient conceptualization of structures.

The solution must include an idea of structures as not constraining, but enabling or facilitating. In one attempt to rescue a concept of structural power that is not a contradiction in terms, Hugh Ward distinguishes between power derived from two different kinds of resources. ${ }^{82}$ Some resources are personal in the sense that they activate individual-specific relations. Other resources, however, are due to a general setting that makes no distinction among agents from within the same category. These structural resources enable actors or facilitate their actions. They thus differ from personal resources, and control over them can be called, as Ward suggests, structural power.

This reconceptualization of structure is still unsatisfactory. Ward uses the perfect market as his model. The market model can account for the enabling feature of structures only through the provision of resources that agents can use to alter their abilities. The assumption of perfect competition never calls into question the origin and maintenance, that is, the reproduction of market positions. The strength of economic analysis is its understanding of the market dynamics of the established actors. It is still not convincing for the explanation of growth, economic development, or the dynamics of creating competitive advantages. Yet, once one accepts that structures are inherently biased for this reason and tend to reproduce such biases, it becomes clear that one must conceive structures more dynamically. One must in fact expand the small structuralist account of a logic of the market not reducible to agency to one of markets as institutions that work with and through a specific set of intersubjective rules and practices. These structures constitute power practices that are continually allocating and reallocating agents to categories that are differently affected by the working of the bias. After all, not everyone is, say, an employer, and not everyone can or is empowered to be one. Whereas agent concepts are compelled simply to treat this as fate, structural constraint, or (poor) luck, it seems more reasonable to set up a power analysis in which empirical scrutiny determines whether it is in fact a question of luck or power.

Thus, whereas Morriss's solution, passive power, was questionable due to its attempt to integrate bias into the concept of power, Ward's proposal is ber 1987), pp. 593-610. 
insufficient because it leaves the systematic furthering of specific interests out of the entire power analysis by reducing impersonal empowering to the control of preexisting structural resources.

\section{Power analysis including agent power and impersonal governance}

There is a seemingly easy theoretical solution to this problem. Not one, but two concepts are necessary to account for the range of power phenomena, namely, (agent) power and governance. This solution avoids concealing the agent-structure tension within the concept, as Morriss does, or reducing empowering to an objective and general constraint/opportunity, as happens with Ward. This implies a shift away from an economic to an intersubjective and constructivist approach, but the substantial problem of the agent-structure divide remains.

The choice of using "power" as the agent referent of power phenomena and "governance" as the intersubjective referent is conventional. One could have chosen either to use another set of words or to follow Michel Foucault and reserve the concept of power for the impersonal part of power phenomena. ${ }^{83} \mathrm{My}$ decision is to follow more common (English-language) usage and reserve the concept of power for the agent level. In such cases, power concepts have often been accompanied by more impersonal concepts taken from the family of authority. ${ }^{84}$

This dyad of concepts needs a particular theory of agency and structure. With regard to agent power, it requires a dispositional conceptualization of power as a capacity for effecting, that is, transforming resources, which affects social relationships. ${ }^{85}$ Using power as a dispositional concept can account for the first two meanings of structural power.

Governance can then be defined as the capacity of intersubjective practices to effect. This includes both the social construction of options that is at the heart of the Gramscian analysis and the routine mobilizing of bias that affects social relationships, more present in poststructuralist writings. For all their differences, they both conceive cooperation as more than a phenomenon of an instrumentalist relation, where one looks for the best way to "cooperate under anarchy" or where the regimes, as an outcome of this instrumentalist

83. The French language distinguishes between puissance (Latin potentia) and pouvoir (Latin potestas), where the first term refers to a potential or ability and the second, to an act. Moreover, a third term, Pouvoir, is used to denote centralized power or government. Foucault's insistence on the diffusion of power is explicable as a countermove to a traditional conception of sovereign (i.e., centralized) power.

84. See especially Steven Lukes, "Power and Authority," in T. Bottomore and R. Nisbet, eds., $A$ History of Sociological Analysis (London: Heinemann, 1979), pp. 633-76.

85. For a recent and similar definition of power, see Heikki Patomäki, "Concepts of 'Action,' 'Structure,' and 'Power' in 'Critical Social Realism': A Positive and Reconstructive Critique," Journal for the Theory of Social Behaviour, vol. 21, no. 2, 1991, pp. 221-50, at p. 234. 
cooperation, influence the brute clash of forces beyond the resulting invisible hand of the balance of power. Order is conceived of not only as the result of individual forces of will but also as the prior constitution of these forces. The structured international realm is also always a form of society/order/system in which agents are constituted-and not just the other way around. This could be exemplified by the way international discourse on development and its agencies have constructed the particular problematique of development and the so-called Third Worlder who needs to be developed. ${ }^{86}$ It is then under this recognized identity that these agents are either empowered or disempowered to take part in international relations.

Poststructuralists would insist that governance for this reason is not necessarily something material to be attached to some persons and not to others, but a diffused process passing through agents. ${ }^{87}$ It is reproduced and realized via practices, habits, dispositions, and sometimes even through the construction of the agent's identity (see Figure 3). Therefore, one must resist the attempt to invariably "individualize" the origins of power, the genesis of the produced effects. This individualization-necessary for blaming agentsbegins to appear deceptive when one analyzes governance. There the discourse of individual blame is simply misplaced. 88

Allowing for a wide approach to power phenomena does not, however, entail acceptance of all the power approaches presented above. The proposed solution explicitly excludes power analyses that argue for a restriction to an agent-based power concept, for they are compelled to avoid the power-asbenefit fallacy by introducing not a second concept of the power family but a random concept: luck. Keith Dowding's rational-choice approach to power has gone so far as to acknowledge the systematic interest furthering that pushed Morriss to conceive of passive power. Quite consistently, he must then treat it as "systematic luck." This concept refers to the privileges and advantages that stem from the social positions of specific actors, but for which they apparently did nothing. ${ }^{89}$ By reducing systematic bias to a question of luck, this approach leaves out of the picture the daily practices of agents that help to reproduce the very system and positions from which the advantages of the lucky are derived. This means that social reproduction can be understood as a ritual of power that not only rests on those who benefit from the system but also needs all those who, via their conscious or unconscious practices, help to sustain it. There is no

86. Marc DuBois, "The Governance of the Third World: A Foucauldian Perspective on Power Relations in Development," Alternatives 16 (Winter 1991), pp. 1-30.

87. This applies for both of Foucault's later periods. For the 1970s, see Michel Foucault, Surveiller et punir: Naissance de la prison (Discipline and punishment: The birth of the prison) (Paris: Gallimard, 1975), pp. 31-34; and for the 1980s, James Bernauer and David Rasmussen, eds., The Final Foucault (Cambridge, Mass.: MIT Press, 1988), particularly pp. 18-20.

88. For a critique of this unwelcome "interference of conspiracy theory," see Ole Waver, "Tradition and Transgression in International Relations: A Post-Ashleyan Position," Working paper no. 24/1989 (Copenhagen: Center for Conflict and Peace Research, 1989), p. 23.

89. Dowding, Rational Choice and Political Power, p. 137. 


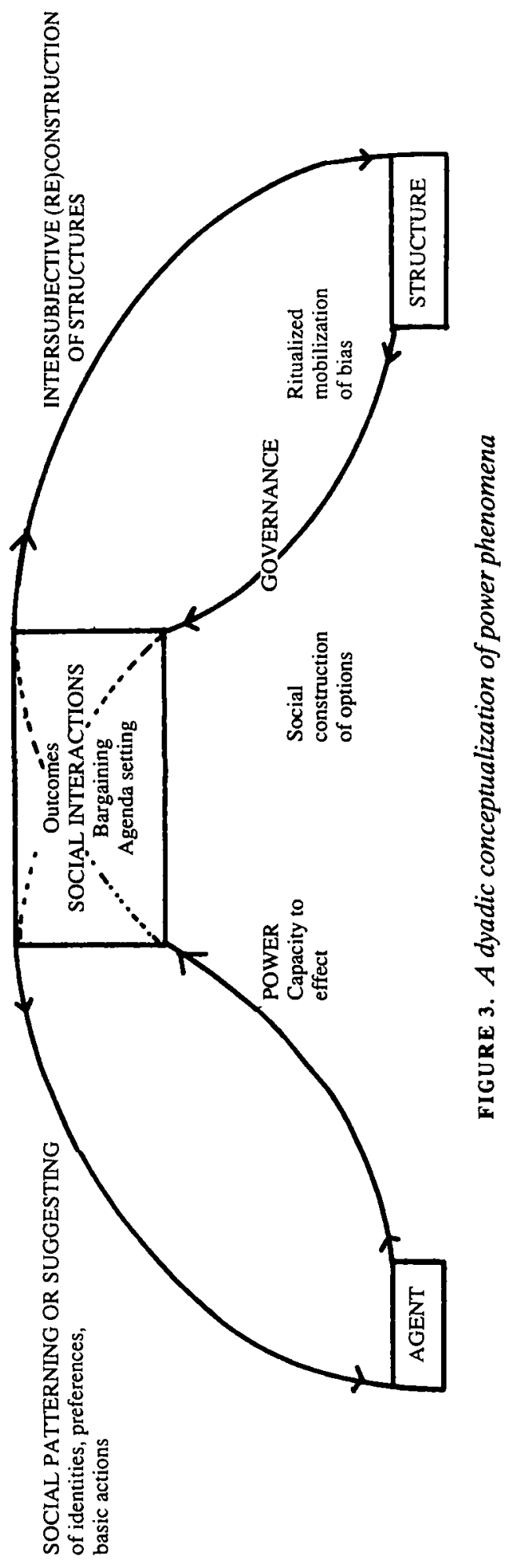


prime mover. Power lies both in the relational interaction of agents and in the systematic rule that results from the consequences of their actions. To quote Foucault, "People know what they do; they frequently know why they do what they do; but what they don't know is what what they do does." 90 Routine actions can constitute rituals of power that suggest the realm of the possible. They construct (and deconstruct) the horizon of the thinkable and feasible that continuously enframes agency and preempts or co-opts alternative discourses and practices.

Power analysis, as the comprehensive account of power phenomena, must call into question the relationship between the different forms of power and of governance. By focusing on power, one needs, for instance, to integrate an analysis of governance via the social patterning of structures. Social interactions mobilize rules for agenda setting that privilege specific agents, that is, the agent's actual power in a bargain is fostered by the system's governance. This is done neither through direct bargaining nor via indirect institutional agenda setting. Only in this way can the power of the German Bundesbank in the above-mentioned example be fully understood. Thus, with a dyad of concepts one can account for Strange's concept of structural power, which she sees as more than the "power to set the agenda of discussion or to design (in American phraseology) the international 'regime' of rules and customs." 91

On the other hand, by focusing on governance, one needs to conceptualize power via the way the identities of agents are constantly redefined. This Foucauldian theme about the intersubjective constitution of agency might appear farfetched in times of stability. Yet, in periods of apparent transition and of an elusive agent and power, Foucault's ideas might be particularly interesting. Just as in Foucault's research program about the constitution of the modern self, so, in international theory, there is a research program about contemporary agency. Moreover, it seems that (1) the constitution of firms, individuals, and nations (not states), for example, as international agents, (2) their definition, and (3) their recognition are resisted by the (realist) international community. Neorealism's inherent conservative bias can at times be healthy but is more and more resented as a disciplinary ritual whose effect consists of marginalizing alternative thought and politics. In other words, in times of an "international" apparently in transition, the theory most resistant to the analysis of change predicts as most probable an eternal return of anarchy. It thereby counters the constitution of recognized international agency and, thus, the latter's power. An analysis of this doxic power of neorealism can identify this discourse and its bearers (academics and statesmen) and can bring them under a general power analysis.

90. Hubert L. Dreyfus and Paul Rabinow, Michel Foucault: Beyond Structuralism and Hermeneutics, 2d ed. (Chicago: The University of Chicago Press, 1983), p. 187.

91. Susan Strange, "The Myth of Lost Hegemony," Intermational Organization 41 (Autumn 1987), pp. 551-74. The quotation is from p. 565. 


\section{Consequences for the study of power phenomena in contemporary IR and IPE}

This reconceptualization of power and governance substantiates already existing critiques of neorealism. Via a conceptual analysis of power that integrates power and governance, neorealism's lack of historicity and its consequent legitimation of status quo power relations can be exposed.

To illustrate the first point, let us again take Krasner's concept of metapower. Krasner conceptualizes regimes as an influence on outcomes, that is, as something linked to the power base, but with a lag. In this way, he used regimes and normative structures as possible resources of power and their potential control as a form of power, namely, metapower. In this context the normative structure becomes an object, similar to material sources, on which to dwell..$^{92}$ This reduction of regimes to objects makes it possible to analyze the structural environment as a set of given constraints and opportunities and not as something that is being continually reshaped by the historically constituted and intersubjectively reproduced societal biases.

In a similar vein, Waltz's formulation practically rules out change at the structural level. By limiting structural change to the first level (anarchy versus hierarchy) and by defining anarchy as the lack of international government, the model constructs a thinking space for change in only one direction. There is change if and only if power becomes concentrated in the hands of one actor and if and only if this hegemony produces a unique sovereignty. This leaves untouched the constitution of the realm we take for granted as international and its significant changes. ${ }^{93}$ However, as the preceding discussion has shown, to account for governance requires a focus on the social construction of such relations and, indeed, of the identity of the relevant actors. ${ }^{94}$ Thus, a dyadic power analysis will inevitably problematize the basic anarchy/sovereignty on which neorealism is built. ${ }^{95}$ In response to Waltz's poor account of change, recent works have tried to integrate change at the second tier of Waltz's neorealism. ${ }^{96}$ Yet, as long as they leave the historicity of the formal dichotomy of anarchy and sovereignty untouched, circularly defined, and reified, such projects cannot remove the basic shortcoming. For many above-mentioned

92. In other words, the reduction of regimes to objects clashes with an implicit shift to an intersubjective ontology; see Kratochwil and Ruggie, "International Organization," pp. 764-65.

93. For a criticism of Waltz's neorealism as unable to account for the change from the medieval to the modern system, see the writings of John G. Ruggie: "Continuity and Transformation in the World Polity: Toward a Neorealist Synthesis," in Keohane, Neorealism and Its Critics, pp. 131-57; and "Territoriality and Beyond: Problematizing Modernity in International Relations," International Organization 47 (Winter 1993), pp. 139-74.

94. Alexander Wendt, "Anarchy is What States Make of It: The Social Construction of Power Politics," Intemational Organization 46 (Spring 1992), pp. 391-425, and, in particular, p. 397.

95. For a thorough appraisal of the concept of sovereignty, see the writings of R. B. J. Walker; for example, "State Sovereignty and the Articulation of Political Space/Time," Millennium 20 (Autumn 1991), pp. 445-61.

96. See Barry Buzan, Charles Jones, and Richard Little, The Logic of Anarchy: Neorealism to Structural Realism (New York: Columbia University Press, 1993). 
authors who conceptualized structural power, a dyadic power analysis points to a nonformalistic understanding of an international system of rule beyond the "anarchy problematique."

The static concept of structure in economic approaches also explains why Krasner and Caporaso, although referring to the same literature, develop two different concepts of structural power that derive from the ambiguity in Bacharach and Baratz's approach, Krasner, starting from an intentional choice-theoretical approach, sees current regimes as given and conceives of power relations only where intentional attempts to change an existing regime can be detected: the Third World against the international liberal regime (assuming such a thing exists). Yet, regimes are not only a means (as for Krasner) for power relations but are, as Caporaso shows, in fact effecting exactly such power relations. Had Krasner from the beginning of his analysis included a problematization and historization of the impersonally empowered status quo, that is, used a dyad of concepts, this mistake would not have been made. ${ }^{97}$ As a result, Krasner's analysis and neorealist power analysis in general itself tend to normalize specific power relations, namely, the unvoiced power of the status quo.

Thus, and this is the second important point, these very practices of power analysis and power politics are part of an ongoing reshaping and reproduction of legitimate discourses and politics. This implies that the whole power analysis must be conceived of as an intersubjective one. Individual power, understood as ability, is couched in an environment that is not just any objective regime or a position in the market/balance of power but an intersubjective realm where rituals of power continually set the stage.

It seems reasonable to expect that this impersonal empowering should be part of any power analysis. It could not in fact coherently be part of a choice-theoretical version of realism, of an individualist dispositional power approach, or of any approach that objectivizes regimes, balances of power, and/or markets.

Therefore, this power analysis, characterized by a dyad of concepts, can claim not only to avoid some traditional logical fallacies of power concepts but also to retain the major insights present in concepts of structural power. Its task is not to argue that either power or governance or both are always the most significant criteria for the explanation of an event. This is to be judged empirically case by case. But, it makes the claim that conceptualizations that do not unnecessarily exclude power phenomena from the construction of research hypotheses should be preferred, because they place fewer constraints on the answers to be found in empirical analysis.

97. For a convincing account of the dynamics of power positions that accounts for Caporaso's and Krasner's frameworks as different stages of power institutionalizations and struggles, see John Gaventa, Power and Powerlessness: Quiescence and Rebellion in an Appalachian Valley (Oxford: Clarendon Press, 1980), p. 21. 


\section{Epilogue: beyond the unquestioned plausibility of power}

As I have argued, recent concepts of power have endeavored to widen the scope of power analysis to include the three features we have met in the conceptualization of structural power: power as indirect institutional, unintended, or impersonally created effects. These attempts to use "power" to account for an international system of governance or hierarchy or authority highlight the insufficiencies of the concept of anarchy as it is used in traditional IR and IPE theory. "Governance" points to the systematic understatement of effective rule, of authority relations at the international level where the concept of sovereignty in a system of self-help might not meaningfully matter anymore. This has profound consequences for the articulation of neorealist theory. In a system of self-help, the ruling of the international system is simply the result of the clashing of national powers. The international order is made out of the hierarchy of state forces. Therefore, in realist theory, national power(s) become(s) the central variable in explanations. Leaving the system of self-help to whatever a structured or functionally differentiated system entails, however, means that power alone is no longer able to explain the "logic" of the international system. This is the central insight of regime theory. Yet, all the neorealist extensions of the concept of power that are aimed at preserving its central explanatory role have been unsuccessful in integrating important features of a comprehensive power analysis, as shown with respect to the three meanings of structural power. Instead of increasingly widening the concept of power, I propose a dyad of concepts, keeping power as an actor-based concept and not subsuming governance under it. Power analysis is about that link between agent capacities and systematic ruling and cannot be reduced to any of them.

This kind of power analysis prepares the ground for a better understanding of the dynamics of the international system, the political responsibilities therein, and the possible places for change. Even governance that is impersonal is realized via human action. The basic reason to preserve a widened power analysis is hence an obvious emancipatory purpose that this article shares with most structural power analyses. Although the relation between power and governance is far from explaining every single outcome, this approach does not exclude power phenomena a priori. Rather, it leaves the assessment of possible short-term and long-term political action to the empirical case. The governance of the system and its identification of powers are not taken for granted, but its pattern of change is examined via the long-term strategies that were or were not used to influence it. This power analysis does not deny a realm of necessity but allows for a wider conception of political action. Particularly for realists, who tend to believe that politics is the art of the possible, this power analysis points to a wider realm of the possible.

This brings me to a final remark. An inherent risk haunts power analyses: very often, power arguments are so "powerful" as to close debates. They are 
immediately plausible code words; that is, the use of a power argument is sometimes not an explanation any longer but a substitute for one. Instead of opening the analysis, the power argument becomes its final stroke. From being a possible help, it becomes a hindrance to understanding. Yet, this article seeks to show that the concept of power is neither self-evident nor unusable if reworked systematically.

Perhaps this unquestioned plausibility of power is linked to the fact that power politics represented a kind of general international theory. Since the international order, rule, or system was difficult to grasp at first sight, the distribution of power would give us the basic indication of who was responsible for controlling that international system. Power was a shortcut. Yet, once the realist link between agent power and international rule ceases to be clear, power explanations do not carry the same weight as before. The dyad of concepts makes it clear that power alone is not what we were looking for. Power becomes just a specific "momentum" in a wider analysis of power phenomena. In other words, power loses its function as a main theoretical indicator.

Accordingly, the concept of power must accept a more humble place. A concept can do no more than the theory in which it is embedded. By itself, it does not provide such a theory. It is even less of a solution to the missing paradigm in IR and IPE, that is, the satisfactory conceptualization of "the international." Anarchy, system, regime, society, system of rule, and governance are all vague descriptions that hide a central vacuum in IR and IPE theory reminiscent of the concept of the state in domestic political theory. A conceptual analysis of power may be a way to show possible spaces for political action and to lay bare the theoretical vacuum, but it cannot fill it. 